\begin{tabular}{|l|l|l|}
\hline \multicolumn{2}{|c|}{ PublisherInfo } \\
\hline \hline PublisherName & $:$ & BioMed Central \\
\hline \hline PublisherLocation & $:$ & London \\
\hline \hline PublisherImprintName & $:$ & BioMed Central \\
\hline \hline
\end{tabular}

\title{
PDGF-induced cell motility depends on EDG-1
}

\begin{tabular}{|l|l|l||}
\hline \multicolumn{2}{|c|}{ ArticleInfo } \\
\hline \hline ArticleID & $:$ & 1610 \\
\hline \hline ArticleDOI & $:$ & $10.1186 /$ rr-2001-68525 \\
\hline \hline ArticleCitationID & $:$ & 68525 \\
\hline \hline ArticleSequenceNumber & $:$ & 21 \\
\hline \hline ArticleCategory & $:$ & Paper Report \\
\hline \hline ArticleFirstPage & $:$ & 1 \\
\hline \hline ArticleLastPage & $:$ & 3 \\
\hline \hline & & RegistrationDate $:$ 2001-9-18 \\
& $:$ & Received \\
\hline ArticleHistory & & Accepted 2001-3-27 \\
& $:$ 2001-9-18 \\
\hline \hline ArticleCopyright & $:$ & Biomed Central Ltd2001 \\
\hline \hline ArticleGrants & $:$ & \\
\hline \hline ArticleContext & $:$ & 129312211 \\
\hline \hline
\end{tabular}


Peter Terry, ${ }^{\text {Affl }}$

Corresponding Affiliation: Aff1

Aff1 The Long Island Jewish Medical Center, New York, USA

\section{Keywords}

EDG-1, GPCR, guanosine triphosphatase, PDGF, PDGFR, receptor tyrosine kinase

\section{Context}

Platelet-derived growth factor (PDGF) promotes proliferation and migration of mesenchymal cells via its receptor, the receptor tyrosine kinase (RTK) PDGFR. Sphingosine kinase type 1 (SPHK1) produces sphingosine-1-phosphate (SPP), which is released to the extracellular compartment where it binds to the G-protein-coupled receptor (GPCR) EDG-1. Mice in which the genes encoding PDGF, PDGFR or EDG-1 have been knocked out exhibit a similar phenotype of incomplete vascular maturation, resulting from a failure of vascular smooth muscle cells and pericytes to migrate to vessel walls; these cells respond to PDGF. The authors investigated whether the PDGF/PDGFR and SPP/EDG-1 pathways were linked, by studying the effect of EDG-1 on cell motility towards PDGF.

\section{Significant findings}

Migration of cultured cells towards SPP or PDGF was dependent on EDG-1 expression, as edg-1 deletion reduced chemotaxis without affecting activation of PDGFR by binding of PDGF. Furthermore, deletion of $e d g-1$ increased PDGF-induced stimulation of SPHK1 activity in fibroblasts. Conversely, competitive inhibition of SPHK1 reduced both formation of SPP and PDGF-induced fibroblast chemotaxis, effects that were not rescued by overexpression of EDG-1. Phosphorylation of PDGFR (via its RTK activity) in these cells was unaffected, as was chemotaxis towards already synthesized SPP. Suppression of PDGF-induced chemotaxis via Gi-protein inhibition (to interfere with EDG-1 signaling) was unaffected by EDG-1 overexpression. Binding of PDGF to PDGFR increased EDG-1 phosphorylation. The ?-arrestins decouple $\mathrm{G}$ proteins from phosphorylated GPCRs; SPP binding to EDG-1 resulted in translocation of ?-arrestin from the cytosol to the plasma membrane. Redistribution of ?-arrestin was dependent on EDG-1 expression. The G protein Rac regulates cytoskeletal organization and cell motility. PDGF activation of Rac was decreased by edg-1 deletion or inhibition of SPHK1, 
suggesting that Rac integrates signals mediated in turn by PDGFR and EDG-1. The authors concluded that, in a new example of exchange of information between an RTK and a GPCR, PDGF binding results in PDGFR activation, enabling it to activate SPHK1 to produce SPP. SPP is then released to the extracellular compartment, where it binds to and activates the GPCR EDG-1, which in turn activates the $\mathrm{G}$ protein Rac, promoting cell motility in an autocrine and/or paracrine loop.

\section{Comments}

PDGF induces smooth muscle cell migration to vessel walls during states of pulmonary hypertension. As a critical mediator of PDGF signaling, EDG-1 is a potential novel therapeutic target for improving this condition.

\section{Methods}

Cell culture, transient transfection, cell migration assay (Boyden chamber), morphogenesis assay on Matrigel, phosphothioate oligonucleotide treatment, whole cell phosphorylation and immunoprecipitation, laser scanning confocal microscopy

\section{Additional information}

\section{References}

1. Hobson JP, Rosenfeldt HM, Barak LS, Olivera A, Poulton S, Caron MG, Milstien S, Spiegel S: Role of the Sphingosine-1 Phosphate Receptor EDG-1 in PDGF-induced Cell Motility. Science. 2001, 291: 1800-1803.

This PDF file was created after publication. 